\title{
METHODOLOGICAL APPROACH TO INTEGRATE A GIS-BASED ANALYSIS INTO THE DESIGN OF CULTURAL ITINERARIES IN THE FRAMEWORK OF AN INTEGRATED PLAN FOR TERRITORY
}

\author{
R. Merino del Río ${ }^{1,3, *, \text { M. Linares Gómez del Pulgar }{ }^{2}, \text { A. Tejedor Cabrera }}{ }^{1}$
}

\begin{abstract}
${ }^{1}$ Dept. of Architectural Design, University of Seville, Av. Reina Mercedes 2, 41012, Seville, Spain - (rmdelrio, atejedor)@ us.es ${ }^{2}$ Dept. of Graphic Design in Architecture, University of Seville, Av. Reina Mercedes 2, 41012, Seville, Spain - mercedeslgdp@us.es ${ }^{3}$ Dept. of Architecture, University of Florence, Via della Mattonaia 14, Firenze, Italy - rebeca.merinodelrio@ unifi.it
\end{abstract}

\author{
Commission II - WG II/8
}

KEY WORDS: Methodology, Integrated Plan for Territory, Cultural Landscape, Landscape Architecture, Itinerary, GIS

\begin{abstract}
:
The historical concept of heritage, which mostly comprised physical architectural and archaeological evidences, has been extended to the surrounding landscape in the last decades. This tendency has been corroborated by a series of International Charters and the European Landscape Convention of 2000. Landscape, understood as the perceptible part of territory that supports the contingencies throughout history, is subject to protection, management and planning. However, some inherent aspects of territory have been disregarded because of the frantic enlargement of cities throughout the twentieth century at the expense of the rural areas. Territorial heritage, which is fundamental to cultural landscape formation, is currently considered a strategic resource able to guarantee selfsustaining development of peri-urban and rural zones. In many cases, urban investments and planning associated to the enlargement of the metropolitan areas have overlooked this fruitful territorial heritage, making cultural landscapes illegible. This is the case of the cultural landscapes in the buffer zones of the archaeological sites, which are part of a diffuse territorial heritage that requires to be assessed by means of some innovative approaches. Cultural itineraries are presented as a landscape architecture strategy for valorising territorial heritage. Well-targeted design of these itineraries can also contribute to restore the dynamics of cultural landscape formation and to regenerate peri-urban and rural areas by promoting its self-sustaining development. To that end, the conceptualisation and hypotheses posed by some authors of the Società dei Territorialisti/e are used as references. A work methodology to design cultural itineraries is suggested in line with the presumptions of an integrated plan for territory aimed to valorise the territorial heritage. This paper explores in which way a GIS-based analysis can be integrated into the design of a landscape architecture like the cultural itinerary.
\end{abstract}

\section{INTRODUCTION}

The European Landscape Convention of 2000 inaugurated a new trend in Europe that broadened the scope of the historical concept of heritage to the surrounding landscape. Landscape, understood as the perceptible and sensitive dimension of the complex reality that constitutes the territory, acquired a renewed meaning by 1992. During the World Heritage Convention of 1992, UNESCO introduced the expression 'cultural landscape' to refer to that landscape which is "illustrative of the evolution of human society and settlement over time, under the influence of the physical constraints and/or opportunities presented by their natural environment and of successive social, economic and cultural forces, both external and internal" (UNESCO, 1992). UNESCO tried to clear up the existing argument stemmed from the historical distinction between natural and cultural heritage (Poli, 2015). Most part of the protection, management and planning strategies adopted until then were considered disintegrative and inadequate by the end of the twentieth century. Disintegrative in that the narrow, dualistic conception of heritage had led to a territory's decomposition in those areas subject to heritage protection (historical centres, archaeological sites, diffuse evidences, natural parks, etc.) and in those areas subject to economic development (Poli, 2020). Deficient to the extent that the lack of an effective heritage protection in those areas subject to economic development had fostered the deterioration of nonvalorised heritage, until its almost total disappearance.
Since 2000, after the European Landscape Convention ratification and implementation, landscape has been legally recognised, and a series of guidelines have been issued to intervene at a landscape scale. These guidelines would be applicable to all areas that possess heritage values, even in the case of marginal or deprived areas, or when heritage values had not been socially recognised. The quality of the cultural landscapes, now contemplated as the image that casts a certain territory as the result of the interaction between man and the physical environment, is subject to revision, as it is considered that it has a direct impact on human well-being (Manzini, Rizzo, 2011; Paba, 2012; Andreeva et al., 2017). This implies a landscape quality examination not only of those areas with a renowned aesthetic value, but also of those peri-urban or rural areas with heritage values that had been systematically disregarded or even destroyed because of a frantic urbanisation at the expense of the rural areas. Despite the belated establishment of the expression 'cultural landscape' and the recent institutional and economic support to investigation, many laboratories and university groups have researched for years on innovative methodologies to intervene at a territorial scale (Dematteis, Governa, 2005; Paolinelli, 2015; Matteini, 2017). To face this new scenario and to channel the academic, institutional and entrepreneurial activity, the Società dei Territorialisti/e was established in Florence in 2011. It is precisely in Italy where most part of its work is circumscribed (e.g. Puglia's Piano Paesaggistico Territoriale Regionale or Tuscany's Piano di Indirizzo Territoriale con valenza di Piano Paesaggistico).

* Corresponding author 
Some of the questions that must be asked when undertaking actions of protection, management or planning of cultural landscapes are related to the nature of the object on which the intervention will be conducted, its detection and identification, or the sort of instrument or strategy to carry out these actions. This scientific discussion - historically limited to the architectural discipline - is extended to the territorial sphere and turns multidisciplinary with the new paradigm after the ratification of the European Landscape Convention of 2000. Although this guarantees a greater effectiveness of the answers, it also entangles a decision-making that is already difficult per $s e$ if we consider the social and economic implications that every landscape intervention entails. Due to the prevailing bibliographical dispersion, it is necessary to lay a solid theoretical foundation for the later design of consistent actions and strategies. To face the aforementioned uncertainties, the bibliography produced by the Società dei Territorialisti/e is revisited, as the authors' continuous efforts in conceptualisation enable us to establish a well-grounded framework.

Among their bibliography, the following books should be highlighted as they are fundamental in the construction of the territorialist project. In Il territorio degli abitanti (Magnaghi, 1998), a spatial model based on territorial heritage valorisation is presented like the only one able to effectively counterbalance the devastating effects of a global economy on the territory. Il progetto locale follows this title. This book is a declaration of intent built on the criticism of the metropolitan urban model that, in Magnaghi's opinion (2006 [2000]), is the spatial expression of a global economy. Another title that should be mentioned is Rappresentare $i$ luoghi: metodi e technique (Magnaghi, 2001a). The different contributions speculate about the difficulties and possibilities of applying the graphic design to the integrated plan for territory. Magnaghi's chapter (2001b), though far from the graphic question, is considered fundamental. In this chapter, he defines some basic concepts that are continuously cited by other territorialist authors in their texts. A key book to understand the territorialist programme is Il territorio bene commune (Magnaghi, 2012), which was published on the occasion of the establishment of the Società dei Territorialisti/e. Here, the main goals of the territorialist project are identified. Finally, it should be mentioned Regole e progetti per il paessagio (Poli, 2012). This compilation of writings is essential to comprehend the conceptualisation and previous works of specialisation that led to the creation and approval of the current Tuscany's PIT with value of landscape plan.

In addition to these isolated titles, there are others specially interesting because of their thematic biases. The first series of titles deals with civil participation and participative processes in the construction of the territory. Percorsi condivisi (Allegretti, Frascaroli, 2006) belongs to this series. A second series is focused on the practical implementation of the theoretical research. Patto città campagna (Fanfani, Magnaghi, 2010), Agricoltura paesaggistica (Poli 2013a), La bioregion urbaine (Magnaghi, 2014a) or La regola e il progetto: un approccio bioregionalista alla pianificazione territorial (Magnaghi, 2014b) are some of the titles in this line. Finally, those books focused on a methodological approach or on the problems stemmed from the conceptualisation are included in a third category, where we find La rappresentazione identitaria del territorio: Atlanti, codici, figure, paradigm per il progetto locale (Magnaghi, 2005), Archetipi di territorio (Marson, 2008) or Invarianti strutturali nel governo del territorio (Maggio, 2014).

\section{AN INTEGRATED PLAN FOR TERRITORY FROM HERITAGE: CONCEPTUALISATION AND METHODOLOGICAL APPROACH}

\subsection{From cultural landscape to territorial heritage}

Cultural landscape has acquired a central role in the European agenda and the latest regional and local planning, as it is considered to be the bearer of identity and heritage values. These values do not exclusively refer to the perceptible dimension of the territory in a certain moment, but fundamentally refer to those elements that have shaped and characterised the historical construction of the territory - insofar as the cultural landscape is defined as a landscape which is illustrative of the co-evolution of culture and nature throughout history -. Thus, these values refer to a structural, deep dimension of the territory. Actions on the cultural landscapes should be then transferred to the substantial and physical reality on which the perceptible image is built, to the reality that actually gives a historical value to the territory, i.e. to those elements that bear in themselves the identity and heritage values. Accepting that the cultural landscape is the sensitive expression of a certain territory - understood the territory as the result of the joint evolution of culture and nature -, it is concluded that those elements that are believed to bear the identity and heritage value are such because they constitute themselves the substantial evidences of this co-evolution. The territorial heritage is subsequently defined as the arrangement of elements that show evidence of the joint evolution of culture and nature. Magnaghi includes the dynamic component of territorial heritage to this reflection. Territorial heritage is, in his opinion, an alive sediment that should be subject to transformations: "When we discover (and analyse) the territorial heritage, we found ourselves talking about a complex, living, always-evolving sediment" (Magnaghi, 2001a, p. 10). In a more recent essay, Magnaghi (2012, p. 25) states that territorial heritage is comprised by environmental, urban, energetic, agroforest heritage; as well as by the collective memory, the know-how or the sociocultural models. Consequently, he supports the dual nature of territorial heritage. It is formed by the substantial sediments, but also by some immaterial legacies. Clearly, this intangible heritage does not possess a physical dimension, but its knowledge and transmission are fundamental to make the territorial heritage grow in accordance with the rules imposed by every place or location.

Regarding the concept of territorial heritage, in a recent chapter, Poli (2020) depicts an interesting reflection on its polemic semantic evolution, as well as the differences between the concepts of territorial heritage, territorial resource and territorial capital. She concludes that the territorial heritage possesses an inherent value of existence, which does not require to be discovered or valorised. Meanwhile, territorial resources and territorial capital have a value of use, i.e. they only exist insofar as a certain community or society has considered, in a certain moment, to give to a territorial asset a specific value and exploit it. Both Poli and Magnaghi are in favour of preserving the elements - or "values" - that constitute the territorial heritage, even if those elements or assets had not been valorised and considered as resources at the present historical period. Every asset that is part of the territorial heritage of a certain place constitutes a potential resource, as it carries genetic information about the construction of the territory, which is essential to undertake actions aimed at restoring the dynamics of cultural landscape formation, an information that is believed to be its actual value of existence. The territorial resource could be thus defined as that element, which is constituent of the territorial heritage, whose value of use has been socially activated. 
This activation is possible to the extent that, as part of the territorial heritage, it has a value of existence that makes it worthy of being valorised and preserved. When this uncovering and valorisation of the territorial heritage become the centre of the planning actions in a certain area or region, we are then talking about a territorialist approach to the design of the settlements. This design can be considered self-sustaining when, as a result of the assimilation and the learning processes, some inherent laws that rule the landscape formation are extracted and used in the design of a strategic scenario able to guarantee a local socioeconomic development limited by the territory's own capacity. It is observed a transfer of the decision-making competences to the institutions and the administration, the only ones able to promote actions for planning nowadays. The citizenship exclusion of the planning processes and the decisionmaking is perceived as a structural deficiency because of the fundamental role of society in the historical construction of the territory and the cultural landscape formation. Cultural landscapes are, in fact, the reflect of the necessities and desires of a community on the territory. This is why in many initiatives of the Società dei Territorialisti/e, some authors explore the possible implementation of civil participation in the uncovering and valorisation of the territorial heritage, as well as in the restitution of the dynamics of cultural landscape formation. The proactive valorisation of heritage, what Poli (2015, p. 134) defines as "patrimonializzazione proattiva", can be only achieved through these participatory processes.

\subsection{Definition of a territorial paradigm}

For making progresses towards an enlargement of the territorial heritage, Società dei Territorialisti/e supports a collective approach to the current problem of de-territorialisation through an integrated plan for territory. This integrated plan is regarded as a prior organisation of planning actions. In socioeconomic terms, its aim - as compared with conventional territorial planning - is to promote the advent of a self-sustaining model of development, limited by the internal laws of each territory and able to last over time as it is ruled precisely by its constitutive principles (Becattini, 2015, p. 89-100). This integrated plan is materialised in the form of instruments, strategies and initiatives of different natures, that operate at several scales and on various actors. Because of the temporal construction of the territory, it is essential to define a time-based territorial model that allows us to comprehend its evolution and the sedimentary nature of the territorial heritage as the basis for undertaking future actions.

In the bibliography, it is observed how the authors frequently refer to the TDR model in an attempt to explain the complex nature of the territory (Magnaghi, 2001b, p. 24; Poli, 2001, p. 3641; Gisotti, 2017, p. 111; Tarpino, 2017, p. 54-57). It is Raffestin (1984) who first introduces this model in the scientific scene. The main strength of this model is that it reveals the historical construction of the territory as the result of the co-evolution of the settlements and the environment. TDR model constitutes an epistemological method that pursues the scientific knowledge of the territory and that is built on three sub-processes: the territorialisation, the de-territorialisation and the reterritorialisation. He proposes a feasible model in which the three sub-processes are related and articulate the entwined reality of the territorial construction (Raffestin, 1984). He places the preceding territorialisation on the bottom, something he links to the history of the places. This is a stable phase on which the other episodes are superimposed. Over this layer, he represents the current process of de-territorialisation with a perpendicular plane. Finally, he places the future territorialisation on the top of the scheme. It is by means of a suitable planning that the original balance can be partially recovered. Thus, he represents an anamorphosis in which, after the de-territorialisation and the reterritorialisation, the plane tends to stabilise, retaining some traces of the past crises.

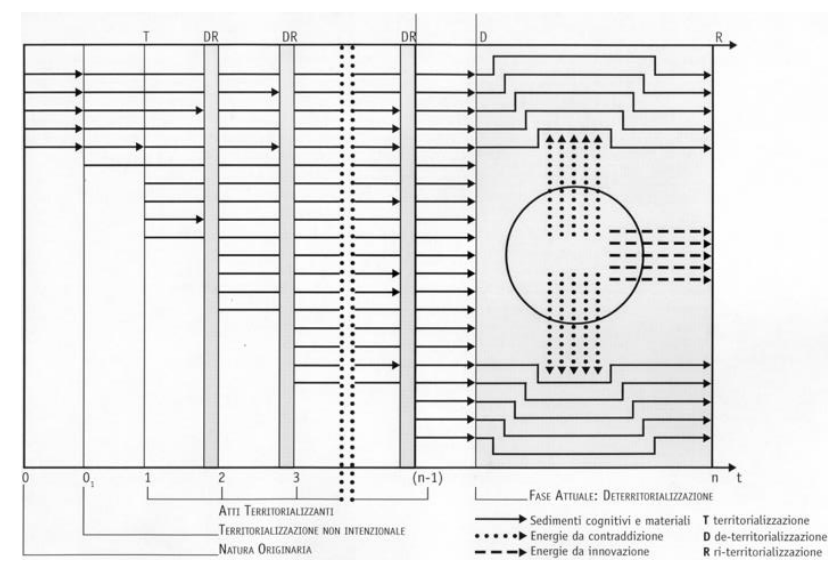

Figure 1. Alberto Magnaghi. Scheme of the territorialisation process (Magnaghi, 2001b, p. 28).

The scheme proposed by Magnaghi (Figure 1) is designed on Raffestin's model albeit it is centred on the phases of territorialisation and de-territorialisation. In this scheme, some additional elements are included in an attempt not only to structure the scientific knowledge of the territory, but also to analyse the territorial heritage's nature and its implication in the historical evolution of the territory (Merino, 2020). The scheme also enables us to locate those elements that are being challenged by a rationalist, exclusively economic-growth-oriented planning (this is the case of the cognitive and material sediments) or those elements that are crucial to make progresses towards a new phase of re-territorialisation (the case of the innovative and conflicting energies). The starting point is the primitive moment when the territory has suffered no anthropologic alteration. Several episodes of territorialisation, $0-0_{1}, 0_{1}-1$ y $1-2$, take place afterwards. Each phase is characterised by a series of relationships between the settled community and the structuring elements, which are adhered like sediments to the existing image of territory. These rapports are perceived as characteristic of the preceding phases in the following stages. The points 2,3 and $(n$ 1) represent the so-called historical ruptures. In these periods, society looks into the territory for new answers different to those of the preceding phase. This search entails different anthropologic constructions and practices. Despite the negative connotations linked to the destruction of territorial heritage boosted by the current practices and trends in heritage protection -, those processes that took place during the historical ruptures are inseparable from the creation processes and evolution. As stated by Choay (2008, p. 78 ): "all cultures and societies have been built and developed by destroying. Demolition is a historical need". At the point $n$, which Magnaghi places at the beginning of the present phase of industrialisation, it is observed how the process of re-territorialisation that should accompany every process of de-territorialisation does not take place. Thus, reterritorialisation is undefinedly postponed. In this phase of generalised de-territorialisation, cultural landscape formation understood as the obtention of some imprints that manifest the joint evolution of the settlements and the environment - is interrupted. There is no dialogue, nor a reading of the territory aimed at searching for some answers that could orientate the design of the settlements, but a superimposition of an artificial order that is neither grounded on nor restricted by the physical limitations of the territory. 
In the scheme, the integration and identification of the elements that constitute the territorial heritage for each phase allow us to study the phenomenon of territorialisation from two complementary perspectives, the synchronic and the diachronic. This distinction is necessary to define the long-standing structure or the rules for the transformation of the territory. As compared with the diachronic standpoint of Raffestin's TDR scheme, Magnaghi's scheme makes visible the object of both diachronic and synchronic studies about the historical construction of territory. The choice of this territorial paradigm implies to provide any future intervention with a clear purpose. Every action, from landscape planning to the territorial plans, is built on this diachronic diffraction and tends to the re-territorialisation, i.e. aims to recover an imperfect balance based on the previous status. In this sense, the present disruption in the creation of rapports between society and the environment, as a consequence of the effects of globalisation, supposes our departure point.

This time-based spatial model is elaborated in parallel to a selfsustaining model of economic development that is focused on the enlargement of the territorial heritage. As recalled and analysed in the paragraphs above, this time-based model enables to assess the evolutionary nature of the territorial heritage. It is defended that any operation on cultural landscapes requires a preliminary translation of the distinctive identity values into the substantial reality, i.e. to the territorial heritage and other representative elements. These distinctive features that characterise the cultural landscape are subject to change, in that territorial heritage - its deep substratum - is a living sediment. If actions on the territory benefit from this time-based spatial model, it follows that actions on its perceptible dimension, cultural landscape, can also benefit from it. In this sense, the time-based model enables us to discover the dynamics of cultural landscape formation, something essential if we are to restore them through the itineraries.

\subsection{Analytical methodology towards an integrated plan for territory}

Magnaghi's truly meritorious achievement is the design of a methodology that he defines as "analytical", based on the three phases of the TDR process mentioned above. The different actions that lead to the integrated plan for territory are ordered in accordance with this method. This methodology puts forward some correlative targets, which stemmed from the territorial sediments and the innovative and conflicting energies identified in the TDR model. The systemic activation of this targets guarantees the return to the territory (Magnaghi, 2001b). After reviewing the bibliography and verifying the existing differences between the writings and the essays, three acts are distinguished: two in the structural part and one in the strategic one (Figure 2). The change of name of the parts - from "project" and "plan" to "structural" and "strategic" - manifests Magnaghi's willingness to separate the main purposes from the instruments, in order to give more freedom on how to proceed to the experts and the rest of actors involved. In the last version, the first structural part, which refers to the primitive phases of territorialisation and the present phase of deterritorialisation, is dissociated from the second strategic part, which aims to make progresses towards a phase of reterritorialisation and possesses an important utopian character (Choay, 2008, p. 47-50).

In first place, because of the fundamental role acquired by the territorial heritage in the production of an integrated plan for territory - whose main purpose is the territorial heritage's amplification -, the starting point of any strategy, either integral or partial, will be its detection and identification. First act refers to the past processes of territorialisation (Pazzagli et al., 2017, p. 13).
To detect and identify the territorial heritage, two parts are distinguished. The first part consists in the elaboration of a history of the territory that helps us to understand the rhythm and intensity of the processes of territorialisation that have led to the current state of the territory (Poli, 2017, p. 42-43). The second is the recognition and synthesis of the cognitive and material sediments that have been deposited during the different phases of territorialisation. This action pursues the reconstruction of the process of sedimentation that has led to the present state of the territorial heritage. The main purpose of the study and the interpretation of the historical process of sedimentation is the analytical description of the identity of the place and of the territorial heritage (Magnaghi, 2001b, p. 15). In the second act, a statute of place should be elaborated, a constitutive document strongly linked to the disciplines of urbanism and territorial planning, which emerged within the territorialist research. It is organised in two sections: the description of the structural invariants and the unveiling of the rules for the transformation. The definition of the structural invariants intends to evidence those constitutive systems and rapports that characterise each territory. The stability of these systems and their relations over time guarantees the endurance of the territory, conceived here as a living structure restricted by its own nature. Meanwhile, the rules for the transformation manifest in which way civilizations have related to the environment and have evolved in view of their renewed interests or needs. Finally, in the strategic part, the definition of a selfsustaining local model of development is pursued. The third act contributes to this aim. On the one hand, some strategic prospects for valorising the existing local evidences of the territorial heritage should be elaborated in line with the structural invariants and the rules defined in the statute of place. Magnaghi $(2001 \mathrm{~b}, \mathrm{p}$. 47) refers to that strategic scenario as: "the image of a new civilization, the precise design of the future landscapes of each place, deeply rooted in the identity of the places and nature, in the choice and the valorisation of new actors and behaviours [...], that pursues the sustainable transformation of the city and the territory". On the other hand, it is necessary to redefine the valorisation models, the instruments of planification and the government systems. Civil participation is fundamental to elaborate the statute of place, but also to define the future prospects and the renewed competences. Società dei Territorialisti/e defends a stronger civil involvement - by means of some participative processes - that would contribute to overcome the current system of government and move towards a new system of local governance (Poli, 2013b, p. 21).

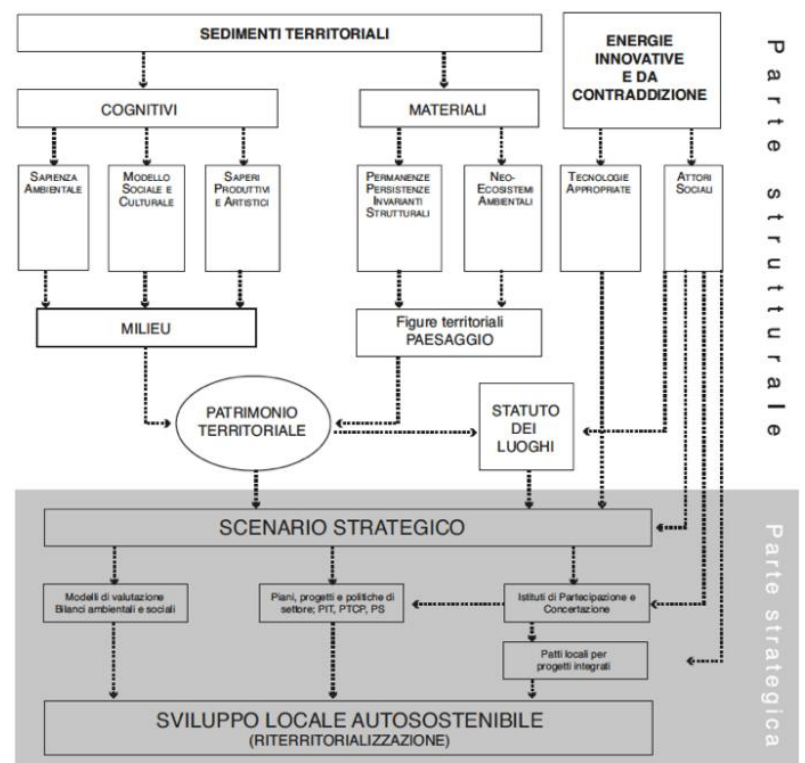

Figure 2. Alberto Magnaghi. Analytical methodology towards an integrated plan for territory (Poli, 2011a, p. 57). 


\section{THE ARCHITECTURAL INTERVENTION IN THE FRAMEWORK OF AN INTEGRATED PLAN FOR TERRITORY}

Despite the numerous advances in the field of territorial and landscape planning, it is observed that there are serious difficulties to effectively implement protection, management and planning actions on the cultural landscapes. Two important hurdles to a good practice on the territory are detected. On the one hand, the difficulty or the incapacity to design an innovative, regulatory framework, able to integrate different actors, which has been defined as the integrated plan for territory. On the other, the lack of a protocol to intervene at a smaller scale - easier to manage - establishing the stages to follow to develop partial strategies that contribute to an integrated plan for territory, as they are built on the same integrating logic and pursue some common objectives. There are several reasons for promoting partial interventions in the framework of an integrated plan for territory. In first place, the alignment of the methodology with the territorialist assumptions enables us to refer to a physical, substantial reality, i.e. the territory, when working on the cultural landscapes. Secondly, the integral, more extensive meaning of the concept of territorial heritage eases the organisation of those material sediments that constitute the diffuse archaeological and architectural remains. Finally, the valorisation and reactivation of the territorial heritage, aimed to restore the dynamics of cultural landscape formation, contribute to increase the territorial heritage mass. This increasing is the basis for guaranteeing the selfsustaining development of the local settled community. In the following paragraphs, an intermediate theoretical framework, which is consistent with the scale and scope of the architectural intervention on the cultural landscape, will be established. This framework is a reduction of the analytical methodology underlying the integrated plan for territory.

Focusing on the design of the cultural itineraries, as the specific strategy for valorising the territorial heritage, the intervention protocol revolves around the detection and identification of that territorial heritage. Because of the required conciseness of the architectural design, the material sediments will be considered. However, it should be taken into account that the material sediments are fostered by and nurture the cognitive sediments that constitute the so-called milieu (Governa, 2001). Nowadays these material sediments constitute a mere reflection of all the substantial evidences that have been deposited on the territory over time and that have structured its evolution. Among these material sediments, the permanencies and structural invariants are disjoined from the so-called environmental neo-ecosystems (Saragosa, 1998). A combination of the two for each phase of territorialisation casts a characteristic image of the territory, i.e. a cultural landscape. As compared with other kind of interventions that take diffuse immovable assets as the starting point of a landscape architecture, it is proposed to begin with the historiographical study of the process of territorialisation. After this, an ancillary description of the territorial heritage is extracted that will allow us to recognise the heritage value of the monumental complexes, as well as of those territorial assets that possess identity values that have not been valorised yet. In order to guarantee the framework's construction on the same basis as the integrated plan for territory, it should be first elaborated a history of the territory and a description of the territorial heritage by means of inter- and multidisciplinary research (Tress et al., 2004). As a result of its partial, subjective character, the research tends to focus on several territorial systems. In this sense, it is recommendable to make the description of the territorial heritage as extensive as possible.
As compared with the detection and identification of the territorial heritage, the elaboration of the statute of place is of minor importance when the scope of the integrated plan for territory is reduced to the architectural design on the landscape. Nevertheless, the definitions of the structural invariants and of the rules for the transformation are necessary to design a landscape architecture in the framework of an integrated plan for territory, as they bear the keys to guarantee an increasing of the heritage mass and the selfsustaining development of local communities. Concretely, the structural invariants constrain the architectural action on the cultural landscape. Their unveiling highlights the elements upon which the survival of the territory depends. It is defended that the first implementation of the new technologies should be made at this point. The same cannot be said for the civil participation that had a major role in the elaboration of the statute of place. Magnaghi (2006 [2000], p. 128) defined the statute of place as "the catalyst of a process, provoked by the impact of the identity of place and the new inhabitants". Despite its importance, the implementation of the social actors into the decision-making is removed of this partial method in favour of greater operability. Thus, the responsibility lies on the experts, limited to the professional or the academic sphere.

Magnaghi (2001b, p. 46) presents the strategic scenario as the methodological stage in which "the perspectives and content of re-territorialisation" are defined. This happens after having taken into account "the territorial pathologies, the identity of territorial heritage, the actors to activate for its valorisation and the rules for the transformation that form part of the statute of place". In the architectural practice, this definition leads to the establishment of a mitigated series of socioeconomic prospects, the pre-selection of the territorial assets on which the intervention shall be based, and the corresponding adjustment of indicators and restrictions to take into account when using innovative technologies. Although this definition has its origins in the social actors, the architectural design on the landscape does not directly contemplate this implementation. Nevertheless, the use of some statistical or sociological studies can be encouraged at this point to complete and reinforce the description of the prospects.

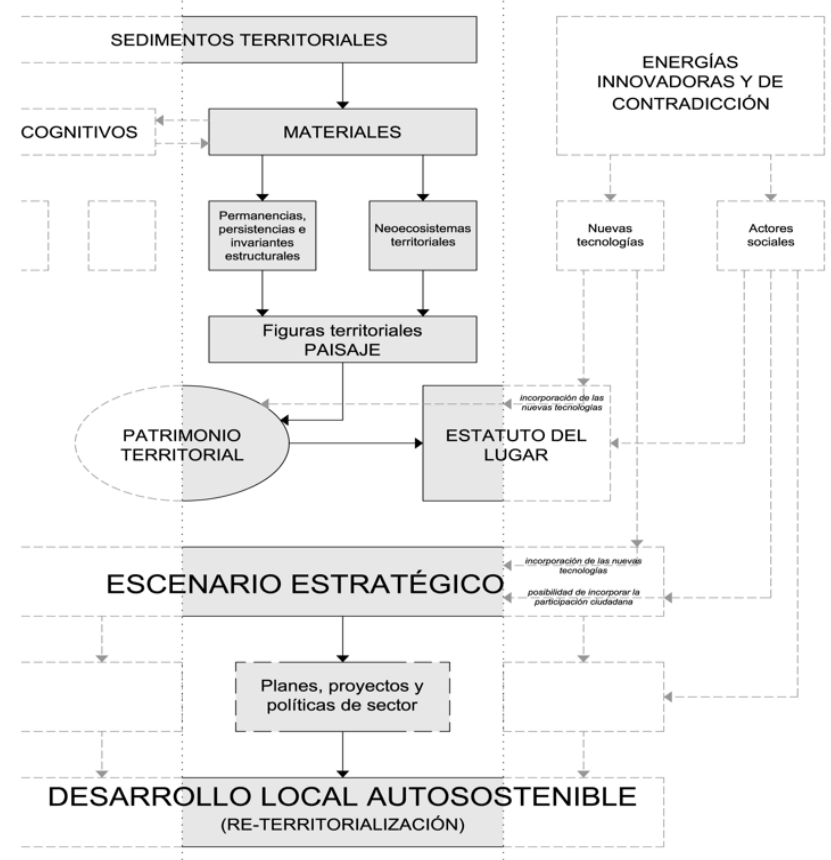

Figure 3. Towards a landscape architecture methodology in the framework of an integrated plan for territory. (C) Rebeca Merino. 


\section{TOWARDS AN INNOVATIVE, GIS-ASSISTED METHODOLOGY TO DESIGN CULTURAL ITINERARIES}

Following a greater concreteness, a specific strategy for designing cultural itineraries in the framework of a landscape intervention is posed. Based on the territorialist postulates, the purpose of the design of the itineraries should not be only the materialisation of a touristic infrastructure, but to make legible an integrated plan for territory. The exclusively touristic focus is in fact in contradiction with an effective valorisation and use of heritage. Territorial heritage is extensively conceived here as the catalyst of an alternative model of settlements that is grounded on the reinforcement of the competences of the local community settled at a certain place (Dematteis, Magnaghi, 2018). Thus, the itinerary should mainly contribute to an ecological planning. It should denote the territorial heritage that has not been already valorised and the reproduction schemes that guarantee the sustainability of the operation for each place. Alternatively, the result can serve as a guide to design some mobility infrastructures in the framework of the so-called eco-museums. Furthermore, this concreteness also affects the study area. In this research, the study area is limited to the buffer zones of archaeological sites. There, it is usual to find archaeological and architectural remains with heritage values dismantled or in a concerning state of abandonment. In accordance with our substantiation, these remains do not only possess value of use - to the extent that its fruition is linked to the production of durable, sustainable wealth -, but they also have value of existence - as they convey genetic information on the historical construction of the territory -. It is this value of existence that Volpe (2012) claims to be the study object of a new discipline, the archaeology of territoriality. In his opinion, this new discipline should be continuously dialoguing with transdisciplinary teams (Volpe, Goffredo, 2014).

Our method takes as a starting point the analytical description of the identity of place through the study of the history of the territory and the evolution of the substantial territorial heritage. These objectives are materialised in the following actions: [1] the establishment of the phases of territorialisation and the historical ruptures, [2] the description of the morpho-type for each phase of territorialisation and [3] the study of the evolution of the morphotype. Although the first one should necessarily contemplate all the elements, the last two can be mostly centred on the rapports between settlements and mobility infrastructures. The three actions are carried out through a comparative analysis of primary and secondary sources: texts, historical cartography, plans, drawings or viewfinders. Recent work on the application of the first action to the case study of Itálica focuses on the effective integration of all these data (Merino, Tejedor, Linares, in press). Because of the biased, multidisciplinary nature of this analytical description, the representation of the identity of place can be made through descriptive memories, plans, maps or drawings. GIS are incorporated in this first phase - something unforeseen in Magnaghi's original scheme - as these systems seem to be appropriate to develop advanced spatial analysis and to visualize georeferenced data (Howey, Brouwer Burg, 2017). On the one hand, the visualization of some territorial assets currently considered heritage values and their cataloguing by date, allow us to outline some ancient settlement patterns that are not graphically recorded or scientific literature fails to georeference. On the other hand, some GIS-based applications allow us to calculate the least cost paths, like r.drain of GRASS, or to make visibility analyses, like .viewshed of ArcGIS of Visibility Analysis of QGIS. These applications and plugins are commonly used by archaeologists to pose hypotheses about the primitive movement throughout the territory (Llobera et al., 2011;
Verbrugghe et al., 2017) or to verify the relationship between the settlement patterns and the visual control of the territory (Galmés Alba, 2015). In our case, GIS are useful to establish the phases of territorialisation and to define the characteristic morpho-types. The superimposition and sequential visualisation of the morphotypes enable us to identify the material sediments from each phase of territorialisation and to analyse their acceptance or refusal in the consecutive phases.

After that, information from the historiographical analysis should be synthesized aiming to achieve a suitable basis for working on the design of cultural itineraries in the framework of an integrated plan for territory. Because of the strategic limitation of the itinerary and the essential role of the description of the structural invariants and the rules for the transformation in the integrated plan for territory, the extraction of these invariants and rules should be the objective of the actions. Social implication of nonexperts in this extraction is not considered here. The description of the territorial heritage follows thus the synchronic and diachronic analysis of the morpho-types that have characterised landscape for each phase of territorialisation. Territorial heritage possesses a long-standing structure and some inherent laws of transformation. Poli $(2013 \mathrm{c}$, p. 52) suggests the need for generating three maps: the first one about territorial and landscape heritage in accordance with the four structural invariants, the second one about the elements and heritage values - which synthesizes the description of the dynamics of transformation that have got a negative impact on the territory and, finally, the third one dealing with landscape quality objectives that summarises and integrates the policy oriented goals. Thus, three are the main actions in this stage. First, [4] the elaboration of a map to identify the territorial heritage in accordance with the structural invariants - constituted by the oroand hydrographical structure, the hierarchical organisation of the settlements and infrastructures, the land-use partitions and the main structures of organisation of territory (Poli, 2011b,p. 23) After that, [5] the elaboration of a map of the long-standing structure to shed light on those more stable, territorial elements. Finally, [6] the definition of the rules for the transformation that have had an impact, either positive or negative, on the landscape formation. The map of the long-standing structure, built on the temporal sequence of morpho-types, is suggested to be made by creating some kind of depth-map. Eetvelde and Antrop (2009) use depth-map to conduct some case studies that allow them to identify the key elements to be considered in the restitution of the dynamics of cultural landscape formation. These key elements are meant to be those that have the highest social acceptance. The elaboration of a depth-map requires that some indicators are described and data are re-classified through some GIS-based applications, like r.reclass.

In the third stage, to contribute to what we have described as the strategic scenario, it is necessary to develop some kind of [7] guiding map that focuses on those areas suited not only to place the cultural itinerary, but also to made investments that encourage an ecological planning. The promotion of these areas - where there is a larger concentration of heritage values - encourages the restitution of the dynamics of cultural landscape formation and guarantees the sustainability of the interventions. To accomplish this action, it is necessary to generate a locational model, i.e. a model in which the optimal areas to develop different activities are indicated (Díaz et al., 2018). For years, this GIS-based functionality has been used in other disciplines, for instance in economic geography. The descriptive map of the territorial heritage is used as the basis. Data from the map of the longstanding structure become the cornerstone of the operations, as they represent the most stable territorial heritage, that with a 
highest social acceptation. This will guarantee the persistence of the actions over time. To obtain the locational model, it is first necessary to define a series of restrictions and areas of compatibility that will guide the operations with spatial data. In this sense, the rules for the transformation retain useful information on the positive or negative impact of the different interpretations of the territory over time. Concretely, these rules convey information about the elements and rapports that have contributed to the increasing of the territorial heritage mass, as well as on those decisions that have provoked its destruction. To use this data, the rules for the transformation should be converted into some exclusion and compatibility criteria. This way, the final document will provide indications on those areas where the welloriented investments in the development will contribute to an ecological planning of the settlements.

\section{CONCLUSIONS}

Cultural landscape has become the cornerstone of European policies oriented to the reinforcement of local identity through heritage. However, the intricate nature of the concept of landscape, to which a high degree of subjectivity is associated, hampers the effective operations on this dimension of the territory. For this reason, but also because of the pressing need of intervening in some landscapes with heritage values that are threatened by the lack of well-oriented guidelines and of an integrated management, it is necessary to design some intervention protocols to ease the work of experts and the administration. At a scientific level, an excessive spreading and some basic deficiencies are observed. Hence, it is necessary to make a re-conceptualisation prior to suggest any methodological approach. This research is built on the same postulates used by the authors of the Società dei Territorialisti/e for the integrated plan for territory, which lies behind some of the most outstanding landscape plans of Italy. The integrated plan is defined as a topdown organisation of the planning processes geared towards the enlargement of the territorial heritage. Despite the suitability and the proven efficiency of its assumptions, it is observed that the scale and scope of the integrated plan for territory are far from those of the architectural intervention on the landscape. Although an integral enlargement of the territorial heritage may not be achievable by means of a landscape architecture, it is sustained that it is possible to partly contribute to this aim - and therefore to the integrated plan - through bottom-up strategies, such as the cultural itineraries. Itineraries should promote the restitution of the dynamics of cultural landscape formation if they are to support this enlargement. To do this, an intermediate framework is proposed that establishes the convergencies and divergencies in the objectives and methods. Two basic pillars guarantee the itineraries contribution to the integrated plan for territory. On the one hand the conceptualisation and modelling of the specific case study using a time-based paradigm of territory. On the other, the reduction of the analytical methodology to adequate the scope and scale to that of a landscape architecture. Thus, this research is useful not only to determine a method for designing itineraries, but also to the extent that it reflects on the possible reduction of the territorialist methodology to achieve a greater operativity. Instead of being centred on the application of GIS software to the case study - a recurrent subject in the scientific literature -, this writing is focused on the way GIS are adapted to a methodology of design based on the territorialist theoretical principles and objectives. It should be the aim of future research to verify whether the proposed actions for each stage are adequate or not to guarantee the contribution to an integrated plan for territory and to adjust the parameters that limit the use of GIS.

\section{ACKNOWLEDGEMENTS}

This research is framed within the Spanish Ministry of Economy and Competitivity funded project HAR2016-79757-R "Smart Architectural and Archaeological Heritage", coordinated by Prof. Antonio Tejedor, and the Regional Government of Andalusia funded project US-1263780 "Gestión Inteligente y Sostenible del Patrimonio Arquitectónico", coordinated by Prof. Carlos Plaza and Prof. Antonio Tejedor, ascribed to the University of Seville.

\section{REFERENCES}

Allegretti, G., Frascaroli, M.E. (eds.), 2006: Percorsi condivisi. Alinea, Florence.

Andreeva, E., Myslyakova, Y., Glukhikh, P., Ratner, A., 2017: Economic and Social Impact of Modernization on Cultural Values. Journal of International Studies 10(1), 193-208.

Becattini, G., 2015: La coscienza dei luoghi: il territorio come soggeto corale. Magnaghi, A. (prol.). Donzelli editore, Rome.

Choay, F., 2008: Del destino della città. Magnaghi, A. (ed.). Alinea, Florence.

Dematteis, G., Governa, F. (eds.), 2005: Territorialità, sviluppo locale, sostenibilità: il modello SLoT. Franco Angeli, Milan.

Dematteis, G., Magnaghi, A., 2018: Patrimonio territoriale e coralità produttiva: nuove frontiere per i sistemi economici local. Scienze del Territorio 6(0), 12-25.

Díaz, P., Camarillo, J.M., Pérez, J.P., 2018: Relational spatial database and multi-criteria decision methods for selecting optimum locations for photovoltaic power plants in the province of Seville. Clean Technologies and Environmental Policy 20(8), 1889-1902. DOI: 10.1007/s10098-018-1587-2.

Eetvelde, V. van, Antrop, M., 2009: Indicators for Assessing Changing Landscape Character of Cultural Landscapes in Flanders (Belgium). Land Use Policy 26(4), 901-910. DOI: 10.1016/j.landusepol.2008.11.001.

Fanfani, D., Magnaghi, A. (eds.), 2010: Patto città campagna: un progetto di bioregione urbana per la Toscana centrale. Alinea, Florence.

Galmés Alba, A., 2015: Visibilidad y percepción en la construcción de un paisaje prehistórico. Complutum 26(1) 173188. DOI: 10.5209/rev_CMPL.2015.v26.n1.49346.

Gisotti, M.R., 2017: La mesa in valore del patrimonio storico del Piano paesaggistico della Regione Toscana. Scienze del Territorio 5(0), 109-116.

Governa, F., 2001: La dimensione territoriale dello sviluppo socio-economico locale: dalle economie esterne distrettuali alle componente del milieu. In: Magnaghi, A. (ed.): Rappresentare $i$ luoghi. Alinea, Florence, 309-324.

Howey, M.C.L., Brouwer Burg, M., 2017: Assessing the State of Archaeological GIS Research: Unbinding Analyses of Past Landscapes. Journal of Archaeological Science 84, 1-9. DOI: 10.1016/j.jas.2017.05.002. 
Llobera, M., Fábrega, P., Parcero, C., 2011: Order in Movement: A GIS Approach to Accessibility. Journal of Archaeological Science 38(0), 843-861. DOI: 10.1016/j.jas.2010.11.006.

Maggio, M., 2014: Invarianti strutturali nel governo del territorio. FUP, Florence.

Magnaghi, A. (ed.), 1998: Il territorio degli abitanti: società locali e sostenibilità. Dunod, Milan.

Magnaghi, A. (ed.), 2001a: Rappresentare i luoghi: metodi e technique. Alinea, Florence.

Magnaghi, A., 2001b: Una metodologia analitica per la progettazione identitaria del territorio. In: Magnaghi, A. (ed.): Rappresentare i luoghi. Alinea, Florence, 13-51.

Magnaghi, A. (ed.), 2005: La rappresentazione identitaria del territorio. Atlanti, codici, figure, paradigmi per il progetto locale. Alinea, Florence.

Magnaghi, A., 2006 [2000]: Il progetto locale. Bollati Boringhieri, Turin.

Magnaghi, A., 2012: Le ragioni di una sfida. In: Magnaghi, A. (ed.): Il territorio bene comune. FUP, Florence, 11-30.

Magnaghi, A., 2014a: La biorégion urbaine. Petit traité sur le territoire bien commun. Eterotopia France / Rhizome, Paris.

Magnaghi, A. (ed.), 2014b: La regola e il progetto. Un approccio bioregionalista alla pianificazione territoriale. FUP, Florence.

Manzini, E., Rizzo, F., 2011: Small projects/large changes: Participatory design as an open participated process. CoDesign 7(3-4), 199-215. DOI: 10.1080/15710882.2011.630472.

Marson, A., 2008: Archetipi di territorio. Alinea, Florence.

Matteini, T., 2017: Strategie per la conservazione attiva e inventiva dei siti archeologici urbani. In: Ugolini, A. (ed.): Ruderi, baracche e bambini. CEIS. Riflessioni a più voci su di una architettura speciale. Altralinea, Florence, 88-107.

Merino, R., 2020: Definición de un paradigma territorial para la intervención arquitectónica en paisajes culturales con alto valor patrimonial. In: Tejedor, A., Linares, M., López, M., Merino, R. (coords.): Innovación para la gestión integrada del patrimonio, el paisaje y el turismo. EUS, EdUVa, Seville, Valladolid, 50-73.

Merino, R., Tejedor, A., Linares, M., in press: Itálica and the Representation of the Movement throughout Territory: Cartographic Analysis for a GIS-Assisted Design of Cultural Itineraries. In: Agustín, L., Vallespín, A., Fernández, A. (eds.): Graphical Heritage. Springer, Cham.

Paba, G., 2012: Felicità e territorio. Benessere e qualità della vita nella città e nell'ambiente. In: Magnaghi, A. (ed.): Il territorio bene comune. FUP, Florence, 33-56.

Pazzagli, R., Bevilacqua, P., Biagioli, G., Russo, S., 2017: La storia allá prova del territorio. Scienze del Territorio 5(0), 12-18.

Paolinelli, G., 2015: Crosscutting Issues in Treating the Fragmentation of Ecosystems and Landscapes. In: Gambino, R., Peano, A. (eds.): Nature policies and landscape policies. Springer, Cham, 283-290. DOI 10.1007/978-3-319-05410-0_32.
Poli, D., 2001: Attraversare le immagini del territorio. Edizioni All'Insegna del Giglio, Florence.

Poli, D., 2011a: Rappresentazioni identitarie e processi partecipativi per la salvaguardia del patrimonio territoriale. In: Volpiano, M. (ed.): Territorio storico e paesaggio. L'Artistica Editrice, Savigliano, 55-71.

Poli, D., 2011b.: Le strutture di lunga durata nei processi di territorializzazione. Urbanistica LXIII(147), 19-23.

Poli, D. (ed.), 2012: Regole e progetti per il paesaggio. Verso il nuovo piano paesaggistico della Toscana. FUP, Florence.

Poli, D. (ed.), 2013a: Agricoltura paesaggistica. Visioni, metodi, esperienze. Alinea, Florence.

Poli, D., 2013b: Editoriale: Problematiche e strategie per il ritorno alla terra. Scienze del Territorio 1(0), 17-42.

Poli, D., 2013c: The Landscape Plan of the Tuscany Region: An Occasion to Enhance the Knowledge and Awareness of Place. I Quaderni di Careggi 0(5), 51-53.

Poli, D., 2015: Il patrimonio territoriale fra capitale e risorsa nei processi di patrimonializzazione proattiva. In: Meloni, B. (ed.) Aree interne e progetti d'area. Rosenberg e Sellier, Turin, 123140.

Poli, D., 2017: Processi storici e forme della rappresentazione identitaria del territorio. Scienze del Territorio 5(0), 42-53.

Poli, D., 2020: La aproximación territorial como base del proyecto integrado de territorio. Merino, R. (trad.). In: Tejedor, A., Linares, M., López, M., Merino, R. (coords.): Innovación para la gestión integrada del patrimonio, el paisaje y el turismo. EUS, EdUVa, Seville, Valladolid, 18-49.

Raffestin, C., 1984: Territorializzazione, deterritorializzazione, riterritorializzazione e informazione. In: Turco, A. (ed.): Regione e regionalizzazione. Angeli, Milan, 69-82.

Saragosa, C., 1998: L'ecosistema territoriale. In: Magnaghi, A. (ed.): Il territorio degli abitanti: società locali e sostenibilità. Dunod, Milan, 163-179.

Tarpino, A., 2017: Per un'ecologia della memoria: territorio tra passato e futuro. Scienze del Territorio 5(0), 54-58.

Tress, G., Tress, B., Fry, G., 2004: Clarifying Integrative Research Concepts in Landscape Ecology. Landscape Ecology 20(4), 479-493. DOI: 10.1007/s10980-004-3290-4.

Verbrugghe, G., Clercq, W. de, Eetvelde, V. van., 2017: Routes across the Civitas Menapiorum. Journal of Historical Geography 57, 76-88. DOI: 10.1016/j.jhg.2017.06.006.

Volpe, G., 2012: Per un'archeologia e un'Università 'territorialiste'. In: Magnaghi, A. (ed.): Il territorio bene comune. FUP, Florence, 151-157.

Volpe, G., Goffredo, R., 2014: La pietra e il ponte. Alcune considerazioni sull'archeologia globale dei paesaggi. Archeologia Medievale XLI(0), 39-54.

UNESCO, 1992: WHC, Activities, Cultural Landscapes. https://whc.unesco.org/en/culturallandscape/\#1. 